\title{
Tissue and intracellular distribution of rhodanese and mercaptopyruvate sulphurtransferase in ruminants and birds
}

\author{
Ali A. Al-QARawi*, Hassan M. Mousa, Badreldin H. Ali \\ Department of Veterinary Medicine, College of Agriculture and Veterinary Medicine, \\ King Saud University, Buraydah, Saudi Arabia
}

(Received 18 May 2000; accepted 23 October 2000)

\begin{abstract}
Cyanide detoxification is catalysed by two enzymes: rhodanese [thiosulphate: cyanide sulphurtransferase, E.C. 2.8.1.1], and 3-mercaptopyruvate sulphurtransferase [3-MST, EC. 2.8.1.2]. In the present work, the activity of the two enzymes in the crude extracts of different tissues and in the mitochondrial and cytosolic fractions of tissues from some ruminants (camels, cattle and sheep) and birds (chickens and pigeons) have been compared. Rhodanese activity was almost exclusively present in the mitochondrial fraction. In ruminants and chickens the highest activity of rhodanese was found in the liver, followed by the kidney. In pigeons, however, the enzyme activity was the highest in the kidneys. In camels' tissues, the rhodanese activity was significantly $(P<0.05)$ lower than in cattle or sheep, and the enzyme activities in the two latter species were similar. The activity of 3-MST in the crude extract of tissues from camels was similar to that in sheep, but higher than that in cattle. The enzyme activity was equally distributed between the mitochondrial and cytosolic fractions in the liver and kidneys of camels, cattle and sheep.
\end{abstract}

rhodanese / 3-mercaptopyruvate sulphurtransferase / camel / ruminant / bird

Résumé - Distribution tissulaire et intracellulaire du rhodanese et du mercaptopyruvate sulfurtransférase chez les ruminants et les oiseaux. La détoxication du cyanure est catalysée par deux enzymes : le rhodanese [thiosulfate : sulfurtransférase de cyanure, E 2.8.1.1], et le 3-mercaptopyruvate sulfurtransférase [3-MST, EC. 2.8.1.2]. Dans cette étude, l'activité de deux enzymes dans les extraits bruts de différents tissus, et dans les fractions mitochondriales et cytosoliques de tissus provenant de ruminants (chameaux, bovins et moutons) et d'oiseaux (poulets et pigeons) a été comparée. L'activité du rhodanese était presque exclusivement présente dans la fraction mitochondriale. Chez les ruminants et les poulets, la plus forte activité du rhodanese a été trouvée dans le foie, suivi par le rein. Cependant, chez le pigeon, l'activité enzymatique la plus forte a été détectée dans le rein. Dans les tissus du chameau, l'activité du rhodanese était significativement $(P<0,05)$ plus faible que chez le bovin et le mouton, et les activités enzymatiques chez ces deux dernières espèces

* Correspondence and reprints: PO Box 10158, Buraydah, Al Gaseem 81999, Saudi Arabia.

Fax: (966) 6 3813372; e-mail: alibadreldin@ hotmail.com 
étaient similaires. L'activité du 3-MST dans les extraits bruts de tissus de chameaux était similaire à celle trouvée chez le mouton, mais plus élevée que chez le bovin. L'activité enzymatique était distribuée de façon équivalente entre les fractions mitochondriales et cytosoliques dans le foie et le rein des chameaux, bovins et moutons.

rhodanese / 3-mercaptopyruvate sulfurtransférase / ruminant / oiseau / chameau

\section{INTRODUCTION}

Cyanide is known to be one of the most toxic substances present in a wide variety of food materials that are consumed by man and animals.

More than 2000 plant species are known to contain cyanogenic glycosides [27] which upon hydrolysis in the digestive tract release cyanide [32]. Small quantities of cyanide are physiologically detoxified in the animal body to the less toxic thiocyanate (SCN) $[20,21,30]$. The conversion of cyanide to $\mathrm{SCN}$ is considered to be the main pathway for cyanide detoxification [19, 33], and is catalysed by two enzymes: rhodanese (thiosulphate: cyanide sulphur transferase, EC..2.8.1.1), and 3-mercaptopyruvate sulphur transferase (MST-EC. 2.8.1.2.). The two enzymes catalyse the following reactions [21, 28-30, 32]:

$$
\begin{aligned}
& \text { Rhodanese: } \\
& \qquad \mathrm{S}_{2} \mathrm{O}_{3}{ }^{2-} \pm \mathrm{CN}^{-} \rightleftharpoons \mathrm{SO}_{3}{ }^{2-} \pm \mathrm{SCN}^{-}
\end{aligned}
$$

3-MST:

$$
\begin{gathered}
\mathrm{SH}-\mathrm{CH}_{2}-\mathrm{CO}-\mathrm{COO}^{-} \pm \mathrm{CN} \rightleftharpoons \\
\mathrm{H}_{3} \mathrm{C}-\mathrm{CO}-\mathrm{COO}^{-} \pm \mathrm{SCN} .
\end{gathered}
$$

The detoxification product of the two enzymes is SCN. The two enzymes differ however in their substrates and pattern of distribution in different tissues of domestic mammals and birds [4, 6, 7, 10, 14].

It has been shown that the pattern of distribution of these two enzymes might affect the physiological fate of cyanide. Also, the activity of the enzyme in a particular tissue may reflect the ability of that tissue to detoxify cyanide. Therefore in the present work we have attempted to measure the activities and intracellular distribution of the two enzymes in different tissues from some ruminant and avian species. To our knowledge there is little or no information about these enzymes in camels and pigeons.

\section{MATERIALS AND METHODS}

\subsection{Animals}

Tissues from clinically healthy adult camels (Camelus dromedarius), sheep (Ovis aries), and cattle (Bos indicus) were obtained from freshly killed animals in a local abattoir. The tissues included the liver, kidney, spleen, thigh muscle, rumen, omasum, abomasum and duodenum. Healthy adult chickens (Gallus domesticus) and pigeons (Columbia domesticus) were bought locally, killed by cervical dislocation and decapitation and the liver and kidneys were removed. All tissues obtained were rinsed in ice-cold normal saline $(0.9 \% \mathrm{NaCl})$ and immediately frozen at $-20{ }^{\circ} \mathrm{C}$ for not more than a week pending analysis.

\subsection{Tissue preparation}

All tissues were thawed and homogenised in 19 volumes of ice cold $0.2 \mathrm{M}$ phosphate buffer, pH.7.4 for the rhodanese assay, or in 19 volumes of ice cold Tris- $\mathrm{HCl}$ buffer, pH 7.4 for 3-MST assay. Homogenisation was carried out using a Virtis homogeniser. Before homogenisation, parts of the digestive system were washed with normal saline and stripped from the underlying muscular 
layer for mucosal layer separation. The homogenates obtained were centrifuged at $4{ }^{\circ} \mathrm{C}$ for $15 \mathrm{~min}$ at $3000 \mathrm{~g}$ in a Suprafuge 21 refrigerated centrifuge to remove tissue debris. Samples expected to contain high rhodanese activity were appropriately diluted with $0.125 \mathrm{M}$ thiosulphate, and the final results were multiplied by the dilution factor.

\subsection{Rhodanese assay}

Rhodanese was assayed spectrophotometrically by the method of Sorbo [24, 25]. Briefly, the homogenate $(0.5 \mathrm{~mL})$ was added to the reaction mixture that contained $0.125 \mathrm{M} \mathrm{Na}$ thiosulphate, $0.2 \mathrm{M} \mathrm{KH}_{2} \mathrm{PO}_{4}$ and $0.25 \mathrm{M} \mathrm{KCN}$ to give a final volume of $2 \mathrm{~mL}$. After $5 \mathrm{~min}$, the reaction was terminated by addition of $0.5 \mathrm{~mL}$ of $38 \%$ formaldehyde. The thiocyanate formed was determined by addition of an equal volume of ferric nitrate reagent to the reaction mixture [25]. The ferric nitrate reagent consisted of $\mathrm{Fe}\left(\mathrm{NO}_{3}\right)_{3} \cdot 9 \mathrm{H}_{2} \mathrm{O}(100 \mathrm{~g})$ dissolved in $65 \%$ nitric acid $(200 \mathrm{~mL})$ and the volume was completed to one litre with distilled water. The absorbance due to the formation of the red ferrithiocyanate complex was read within $10 \mathrm{~min}$ at $460 \mathrm{~nm}$. A blank was carried through the procedure, except that formaldehyde was added before the homogenate. One rhodanese unit is the amount of the enzyme that catalyses the formation of $1 \mu \mathrm{mol}$ of thiocyanate per min at $25^{\circ} \mathrm{C}$.

\subsection{3-MST assay}

This enzyme was assayed according to the spectrophotometric method of Taniguchi and Kimura [26]. The reaction mixture contained $40 \mu \mathrm{L}$ of Tris- $\mathrm{HCl}$ buffer, $\mathrm{pH} 7.4$, and $15 \mu \mathrm{L}$ mercaptopyruvate and $25 \mu \mathrm{L}$ of $\mathrm{KCN}$. The homogenate was added to give a final volume of $0.5 \mathrm{~mL}$. After $15 \mathrm{~min}$, $0.1 \mathrm{~mL}$ of $38 \%$ formaldehyde was added to terminate the reaction. The colour was developed by the addition of $0.5 \mathrm{~mL}$ of ferric nitrate reagent. The absorbance was measured at $460 \mathrm{~nm}$. Since mercaptopyruvate gives a yellow-green complex upon reaction with ferric nitrate, a control containing no enzyme was prepared, and its reading was subtracted from that of the sample. One enzyme unit is the amount of enzyme that catalyses the formation of $10 \mu \mathrm{mol}$ of thiocyanate under the assay conditions.

\subsection{Protein assay}

This was measured by the method of Lowry et al. [16], using bovine serum albumin as the standard.

\subsection{Mitochondria isolation}

Mitochondria were isolated according to Max et al. [18] as modified by Mousa [20]. Liver or kidney ( $1 \mathrm{~g}$ ) was homogenised with $20 \mathrm{~mL}$ of $0.25 \mathrm{M}$ sucrose solution. The homogenate was centrifuged at $800 \mathrm{~g}$ for 10 min at $4{ }^{\circ} \mathrm{C}$. The supernatant was again centrifuged at $20000 \mathrm{~g}$ for $10 \mathrm{~min}$. After removing the supernatant, the light fluffy layer over the mitochondrial pellet was removed by gentle swirling using sucrose solution. The pellet was then suspended in $2 \mathrm{~mL}$ of $0.02 \mathrm{M}$ phosphate buffer, $\mathrm{pH}$ 7.4. before determining the enzyme activity.

\subsection{Chemicals}

These were analytical Reagent grade (Sigma, St. Louis, MO, USA), and BDH (Poole, Dorset, UK).

\subsection{Statistical analysis}

The values are means \pm SD (number of observations). Differences between species were conducted by the t-test. A P value lower than 0.05 was considered significant. 
Table I. Specific activity of rhodanese (enzyme unit per mg protein) in crude tissue homogenates from camel, cattle and sheep.

\begin{tabular}{lccc}
\hline Tissue & & \multicolumn{2}{c}{ Specific activity } \\
& Camels & Cattle & Sheep \\
\cline { 2 - 4 } & $0.183 \pm 0.04^{*}$ & $1.250 \pm 0.29$ & $0.903 \pm 0.01$ \\
Kiver & $0.027 \pm 0.01^{*}$ & $0.880 \pm 0.29$ & $0.619 \pm 0.14$ \\
Midney & $0.020 \pm 0.01^{*}$ & $0.590 \pm 0.11$ & $0.320 \pm 0.08$ \\
Spleen & $0.017 \pm 0.01^{*}$ & $0.670 \pm 0.04$ & $0.560 \pm 0.09$ \\
Rumen & $0.018 \pm 0.01$ & $0.033 \pm 0.00$ & $0.029 \pm 0.00$ \\
Omasum & $0.016 \pm 0.00^{*}$ & $0.046 \pm 0.00$ & $0.046 \pm 0.00$ \\
Abomasum & $0.010 \pm 0.00^{*}$ & $0.008 \pm 0.00$ & $0.026 \pm 0.00$ \\
Intestine & $0.010 \pm 0.00^{*}$ & $0.003 \pm 0.00$ & $0.014 \pm 0.00$ \\
\hline
\end{tabular}

Values are means $\pm \operatorname{SD}(n=6)$.

$*$ The tissue value in this species was significantly different from the two other species $(P<0.05)$.

\section{RESULTS}

The specific activity of rhodanese in crude extracts from camels, sheep and cattle is shown in Table I. The enzyme was present in all tissue studies, albeit in different concentrations. In the three species, the liver had the highest level of activity. In camels, the activity of the enzyme was significantly lower than that in cattle or sheep $(P<0.05)$ except in the abomasum and intestine, where the rhodanese activity was significantly lower in cattle than in sheep and camels.

No significant differences between the enzyme activity in sheep and cattle were found. Table II depicts rhodanese activity in the liver and kidney of chickens and pigeons. The pigeon's kidney had slightly higher enzyme activity than that of the pigeon's liver, or chicken's liver or kidney. In the chicken, the activity of the enzyme in the liver was higher than that in the kidney.

Mitochondrial and cytosolic rhodanese activities in the liver and kidneys of cattle and sheep are shown in Table III. In both species the mitochondrial enzyme activity was significantly higher $(P<0.05)$ than that in the cytosol, and the enzyme activity in the liver and kidney cytosol in both species was similar. Mitochondrial rhodanese in the

Table II. Rhodanese activity in the liver and kidney of chickens and pigeons.

\begin{tabular}{lccc}
\hline Tissue & Proteins & \multicolumn{2}{c}{ Rhodanese activity } \\
\cline { 2 - 4 } & $\left(\mathrm{mg} \cdot \mathrm{g}^{-1}\right.$ tissue $)$ & $\left(\right.$ units $\cdot \mathrm{g}^{-1}$ tissue $)$ & (units $\cdot \mathrm{mg}^{-1} \mathrm{protein}^{2}$ \\
\hline Liver (chickens) & $228 \pm 26$ & $48.8 \pm 7.9^{\mathrm{a}}$ & $0.214 \pm 0.02^{\mathrm{a}}$ \\
Liver (pigeons) & $190 \pm 12$ & $59.7 \pm 8.6^{\mathrm{b}}$ & $0.314 \pm 0.04^{\mathrm{b}}$ \\
Kidney (chickens) & $160 \pm 07$ & $14.7 \pm 2.3^{\mathrm{c}}$ & $0.092 \pm 0.02^{\mathrm{c}}$ \\
Kidney (pigeons) & $204 \pm 14$ & $86.9 \pm 11.6^{\mathrm{d}}$ & $0.426 \pm 0.0^{\mathrm{d}}$ \\
\hline
\end{tabular}

Values are means \pm SD (number of animals $=6$ ).

Values with different superscript differ significantly $(P<0.05)$. 
Table III. Mitochondrial and cytosolic distribution of rhodanese (enzyme unit per mg protein) in the liver and kidney of sheep and cattle.

\begin{tabular}{lcc}
\hline Tissue & \multicolumn{2}{c}{ Specific activity } \\
\cline { 2 - 3 } & Mitochondrial & Cytosolic \\
\hline Cattle liver & $3.93 \pm 0.24^{\mathrm{a}}$ & $0.039 \pm 0.01^{\mathrm{b}}$ \\
Sheep liver & $3.20 \pm 0.15^{\mathrm{b}}$ & $0.035 \pm 0.01^{\mathrm{b}}$ \\
Cattle kidney & $3.10 \pm 0.06^{\mathrm{b}}$ & $0.030 \pm 0.01^{\mathrm{b}}$ \\
Sheep kidney & $3.42 \pm 0.13^{\mathrm{b}}$ & $0.030 \pm 0.03^{\mathrm{b}}$ \\
\hline
\end{tabular}

Values are means $\pm \operatorname{SD}(n=6)$.

Values on a same column with different superscripts are significantly different $(P<0.05)$.

cattle liver was significantly higher $(P<0.05)$ than in the cattle kidney or sheep liver or kidney. In sheep, the activity of rhodanese was similar in the liver and kidney.

The specific activity of 3-MST in the crude extract from the liver and kidneys in the three species is shown in Table IV. The activity of this enzyme in camels and sheep was significantly higher than that in cattle $(P<0.05)$. The activity of the enzyme in the kidneys of camels was significantly higher than in the kidneys of cattle or sheep.

Table V shows the distribution of 3-MST activity in the cytosolic and mitochondrial fractions of the liver and kidneys of camels, cattle and sheep. The enzyme activity was almost equally distributed between the two fractions in both the liver and kidney. The activity in sheep was slightly but significantly less than in cattle and camels $(P<0.05)$.

\section{DISCUSSION}

In addition to their role in the conversion of cyanide to SCN, rhodanese and 3-MST also catalyse other biologically important

Table IV. Specific activity of 3-mercaptopyuravate sulphurtransferase (enzyme unit per mg protein) in crude extract from different animal species.

\begin{tabular}{lccc}
\hline Tissue & \multicolumn{3}{c}{ Specific activity } \\
\cline { 2 - 4 } & Camels & Cattle & Sheep \\
\hline Liver & $0.017 \pm 0.008^{\mathrm{a}}$ & $0.004 \pm 0.001^{\mathrm{b}}$ & $0.013 \pm 0.006^{\mathrm{a}}$ \\
Kidney & $0.014 \pm 0.004^{\mathrm{a}}$ & $0.005 \pm 0.001^{\mathrm{b}}$ & $0.007 \pm 0.002^{\mathrm{b}}$ \\
\hline
\end{tabular}

Values are means $\pm \operatorname{SD}(n=6)$.

Means on the same line having different superscripts are significantly different $(P<0.05)$.

Table V. Mitochondrial (M) and cytosolic (C) distribution of 3-mercaptopyruvate sulphurtransferase (enzyme unit per mg protein) in the liver and kidney of camels, cattle and sheep.

\begin{tabular}{llll}
\hline Tissue & & Specific activity & \\
\cline { 2 - 4 } & Camels & Cattle & Sheep \\
\hline Liver (M) & $1.47 \pm 0.21$ & $1.32 \pm 0.12$ & $0.98 \pm 0.11^{*}$ \\
Liver (C) & $1.33 \pm 0.32$ & $1.24 \pm 0.23$ & $0.92 \pm 0.17^{*}$ \\
Kidneys (M) & $1.28 \pm 0.26$ & $1.46 \pm 0.36$ & $0.96 \pm 0.20^{*}$ \\
Kidneys (C) & $1.22 \pm 0.31$ & $1.16 \pm 0.21$ & $0.84 \pm 0.24^{*}$ \\
\hline
\end{tabular}

Values are means $\pm \operatorname{SD}(n=6)$.

Asterisks denote significant difference from the corresponding values in camels and cattle $(P<0.05)$. 
reactions such as the formation of an ironsulphur chromophore of ferrodoxin, an important component of the respiratory chain and the overall metabolism of sulphur $[9,26]$. They also catalyse the direct oxidation of reduced thioredoxin by reactive oxygen species [23]. It is noteworthy, however, that 3-MST is also found in erythrocytes and in a variety of subcellular compartments including the cytosol, nucleus, mitochondria and endoplasmic reticulum [31]. With a thiol serving as the substrate for 3-MST instead of cyanide, a persulphide is then formed. One biological function of this enzyme may be to contribute to the endogenous sulphane sulphur pool by forming persulphides [31].

Except in the pigeon where the highest activities of rhodanese and 3-MST were in the kidney, the activity of the two enzymes in all the other species studied here was the highest in the liver. This reflects the importance of the liver in cyanide detoxification. It is noteworthy that in addition to the pigeon, some other species also have the highest activity of rhodanese in organs other than the liver. For example the highest activity of this enzyme in dogs was found in the adrenal glands [12]. In several species the digestive system has been shown to contain higher activities of rhodanese than the liver $[2,5,6]$.

Rhodanese activity in the livers of the animals studied here was highest in cattle, followed by sheep, chickens, pigeons and lastly camels. This corroborates earlier data obtained in camels, sheep and goats, which indicated that hepatic activities of several drug metabolising enzymes were highest in goats and lowest in camels (for a recent review see [3]). The reason(s) for the lower activity of rhodanese activity in the camel liver are not certain but may, at least partly, be ascribed to the feeding behaviour of camels. These animals spend more than $70 \%$ of their total grazing time on plants reaching a height of one meter or more [1], and it is known that as plants grow older and taller, their contents of cyanogenic glycosides decrease [28]. The presence of rhodanese in ruminal tissue may aid in the detoxification of cyanide released by the action of ruminal flora from ingested cyanogenic glycosides in food. Differences in the functions of the different parts of the digestive systems and the possible differences in the composition of the gut flora in the species studied may have led to the differences in the level of activity of rhodanese seen in these species. Other possible reasons for the lower enzyme activities in camels may be related to anatomical and physiological differences or to relative body size and food intake, since smaller animals are known to consume relatively large amounts of food and vice versa. As it is known that the level of rhodanese in any particular organ reflects the ability of that organ to detoxify cyanide $[5,15]$, it would be expected that sheep and cattle are more rapid metabolisers of cyanide than camels.

The distribution of rhodanese activity in the digestive systems of birds was not investigated here, but it was reported by Aminlari and Shahbazi [5] that the chicken proventriculus contains higher activity of rhodanese than the liver. This is reminiscent of the finding of Ali and Bartlet [2] that the activity of monoamine oxidase, the enzyme that is responsible for degradation of some harmful biogenic amines in the food (e.g. tyramine) is significantly higher in the duodenal mucosa than in the liver. These results allude to the possible function of these enzymes in the digestive system as protectants against poisoning by potentially toxic substances in the food.

Sub-cellularly, we found that in cattle and sheep rhodanese activity was located mainly in the mitochondrial fraction, the activity in this fraction being 90 times greater than in the cytosol. Similar results have been obtained in mice liver [14]. The presence of the enzyme in the mitochondrial matrix may function in the protection of respiratory chain in case of cyanide toxicity. In this work, the activity of rhodanese in sheep was lower than in cattle, and this is 
the opposite of the results obtained by workers in Iran [6]. These differences may possibly be due to differences in type of feed consumed, breed, methodologies used, nutritional status of the animals or to other unknown factors.

The activity of 3-MST in crude extract was lower than that of rhodanese in all the tissues examined here. Others have shown that the activity of rhodanese is about one order of magnitude greater than that of 3-MST [10]. The activity of 3-MST in liver crude extract of camels and sheep was higher than that found in cattle. However, this lower activity of 3-MST in cattle was compensated for by a significantly higher level in the mitochondrial fraction (Tab. V). Unlike the distribution of rhodanese, the enzyme 3-MST was found to be distributed equally between the mitochondria and the cytosol. This distribution may support the contention that 3-MST first detoxifies cyanide in the cytoplasm, and the cyanide that escapes catalysis by 3-MST in the cytoplasm would be detoxified by 3-MST and rhodanese in the mitochondria. Mercaptopyruvate, the 3-MST substrate, may also bind cyanide directly to form a cyanohydrin, and this mechanism may complement the enzymatic pathway to assist in the in vivo detoxification of cyanide [22, 29].

It has been shown that intravenous (i.v.) injection of crystalline bovine liver rhodanese together with appropriate sulphur donors have good therapeutic and prophylactic antidote effects in mice [11]. Ruminants appear to be more susceptible to the effect of cyanogenic plants than monogastric animals [13]. In this work the activities of both enzymes studied were higher in ruminants than in birds, confirming the role of the two enzymes in the detoxification of cyanide in ruminants rather than in monogastric animals. It has been reported that the activities of rhodanese and 3-MST in liver and heart of mallard ducks (Anas platyrhynchos) before and after exposure to cyanide were similar [17]. This confirms our above assertion about the importance of the two enzymes studied in monogastric and ruminant animals. However, despite the abundance of the two enzymes in ruminants' tissues, the administration of small doses of cyanide is lethal. The $\mathrm{LD}_{50}$ for oral $\mathrm{KCN}$ is only $3.8 \mathrm{mg} \cdot \mathrm{kg}^{-1}$ in sheep [8]. Thus, it appears that cyanide detoxification depends on the bioavailability of suitable sulphur donors rather than on the mere presence of the detoxification enzymes, and/or their intracellular distribution.

\section{ACKNOWLEDGEMENTS}

We thank Dr. Idris A. Ibrahim for technical help.

\section{REFERENCES}

[1] Abbas A.M.A., Mousa H.M., Lechner-Doll M., Engelhardt W.V., Nutritive value of plants selected by camels (Camelus dromedarius) in the Butana area of the Sudan, J. Anim. Physiol. Anim. Nutr. 74 (1994) 1-8.

[2] Ali B.H., Bartlet A.L., The effect of furazolidone on monoamine oxidase in the chicken and the influence of the alimentary flora thereon, Br. J. Pharmacol. 71 (1981) 219-224.

[3] Alqarawi A.A., Ali B.H., A survey of the literature on drug kinetics in the camel (Camelus dromedarius) (1995-1999), Vet. Res. Commun. 24 (2000) 245-260.

[4] Aminlari M., Gilnapour H., Comparative studies on the distribution of rhodanese in different tissues of domestic animals, Comp. Biochem. Physiol. B 99 (1991) 673-677.

[5] Aminlari M., Shahbazi M., Rhodanese (thiosulfate: Cyanide sulfurtransferase) distribution in the digestive tract of chickens, Poult. Sci. 73 (1994) 1465-1469.

[6] Aminlari M., Gilnapour H., Taghavianpour M., Vaseghi T., Comparative studies of rhodanese and $\beta$-mercaptopyruvate sulphurtransferase in different organ of sheep and cattle, Comp. Biochem. Physiol. C 92 (1989) 259-262.

[7] Aminlari M., Gholami S., Vaseghi T., Azaraf A., Rhodanese (Thiosulfate: Cyanide sulfurtransferase) in the digestive tract of chickens at different stages of development, Poult. Sci. 76 (1997) 318-320.

[8] Burrows G.E., Cyanide toxicity in sheep: Therapeutics, Vet. Human Toxicol. 23 (1981) 22-28.

[9] Cianci M., Gliubich F., Zanotti G., Berani R., Specific interaction of lipoate at the active site 
of rhodanese (1), Biochim. Biophys. Acta 1481 (2000) 103-108.

[10] Dudek M., Frendo J., Koj A., Sub-cellular compartmentation of rhodanese and 3-mercaptopyurvate sulphurtransferase in the liver of some vertebrate species, Comp. Biochem. Physiol. B 65 (1980) 383-386.

[11] Frankenberg L., Enzyme therapy in cyanides poisoning: effect of rhodanese and sulphur compounds, Arch. Toxicol. 45 (1981) 315-323.

[12] Himwich W.A., Saunders J.B., Enzymatic conversion of cyanide to thiocyanate. Am. J. Physiol. 153 (1948) 348-354.

[13] Kingsbury J.M., Poisonous plants of the United States and Canada, Englewood Cliffs, NJ, Prentice Hall, 1964, pp. 23-26.

[14] Koj A., Subcellular compartmentation and biological functions of mercaptopyruvate sulphurtransferase and rhodanese, in: Cavallini D., Gaull G.E., Zappia V. (Eds.), Natural Sulphur Compounds, Plenum Press, New York, 1980, pp. 493503.

[15] Lewis J.L., Rhoades C.E., Bice D.E., Harkema J.R., Hotchiss J.A., Sylvester D.M. S., Dhal A.R., Interspecies comparison of cellular localisation of the cyanide metabolising enzyme rhodanese within olfactory mucosa, Anat. Rec. 232 (1992) 620-627.

[16] Lowry O.H., Rosenbrough N.J., Farr A.L., Randall A.J., Protein measurement with Folin phenol reagent, J. Biol. Chem. 193 (1951) 265275 .

[17] Ma J., Pritsos C.A., Tissue-specific bioenergetic effects and increased enzymatic activities following acute sublethal peroral exposure to cyanide in the mallard duck, Toxicol. Appl. Pharmacol. 142 (1997) 297-302.

[18] Max S.R., Garbbus J., Wehmen J., Simple procedure for rapid isolation of functionally intact mitochondria from human and rat skeletal muscles, Anal. Biochem. 46 (1972) 576-584

[19] Mintel R., Westly J., The rhodanese reaction mechanism of sulphur-sulphur bond cleavage, J. Biol. Chem. 241 (1966) 3381-3385.

[20] Mousa H.M., Cyanide detoxification in domestic fowl (Gallus domesticus), Ph.D. thesis, University of London, UK, 1982.
[21] Mousa H.M., Davis R.H., Alternative sulphur donors for detoxification of cyanide in the chicken, Comp. Biochem. Physiol. C 99 (1991) 309-315.

[22] Nagahara N., Ito T., Minami M., Mercaptopyruvate sulphurtransferase as a defence against cyanide toxication: molecular properties and mode of detoxification, Histol. Histopathol. 14 (1999) 1277-1286.

[23] Nandi D.L., Horowitz P.M., Westley J., Rhodanese as a thioredoxin oxidase, Int. J. Biochem. Cell Biol. 32 (2000) 465-473.

[24] Sörbo B.H., Crystalline rhodanese. 1. Purification and physiochemical examination, Acta Chem. Scand. 7 (1953) 1129-1136.

[25] Sörbo B.H., Rhodanese, in: Colowick S.P., Kaplan N.O. (Eds.), Methods in Enzymology, Vol. 2, Academic Press, New York, 1955, pp. 334-337.

[26] Taniguchi T., Kimura T., Role of 3-mercaptopyruvate sulphurtransferase in the formation of iron sulphur chromophore of adrenal ferrodoxin, Biochim. Biophys. Acta 364 (1974) 284-295.

[27] Vannesland B., Casetric P.A., Conn E.E., Solomonson L.P., Volini M., Westley J.E., Cyanide metabolism, Fed. Proc. 41 (1982) 26392648.

[28] Vogel K.P., Haskins F., Govz H., Potential for hydrocyanic acid poisoning of livestock by Indian grass, J. Range Manage. 40 (1987) 506-509.

[29] Way J.L., Cyanide intoxication and its mechanism of antagonism, Annu. Rev. Pharmacol. Toxicol. 24 (1984) 451-481.

[30] Westley J.E., Rhodanese, Adv. Enzymol. 39 (1973) 327-368

[31] Westley J.E., Mammalian cyanide detoxification with sulphane sulphur, in: Cyanide Compounds in Biology, Ciba Foundation Symposium, 1988, no. 140 , pp. 201-218.

[32] Wiemeryer S.N., Hill E.F., Carpenter J.W., Krynitsky A.J., Acute oral toxicity of sodium cyanide in birds, J. Wildl. Dis. 22 (1988) 538546

[33] Wood J.L., Biochemistry of thiocyanic acid, in: Newmann A.A. (Ed.), Chemistry and Biochemistry of thiocyanic acid and its derivatives, Academic Press, New York, 1975, pp. 156-221. 